\title{
The Relationship Between Doctors, Patients and the Law in North American and British Literature
}

\author{
VICTOR KENNEDY
}

\begin{abstract}
In common law jurisdictions today, the relationship between doctors and patients is generally considered to be a private one (Dorr Goold and Lipkin Jr., 1999). Like most professions, doctors are governed to a large extent by professional associations with their own Codes of Ethics. To practice medicine in the United States, Canada, or Britain, doctors must be licensed by their local Board or College ${ }^{1}$. Government control of doctor-patient relationships is generally limited to funding, but in a few areas, in particular, those that are considered to be matters of public morality or ethics, criminal statutes can apply. Historically, reproductive rights have often fallen under state control. This paper will compare fictional representations of state interference with reproductive rights in three science-fiction dystopias, Margaret Atwood's The Handmaid's Tale (Atwood, 1985), P.D. James's Children of Men (James, 1992), and Harlan Ellison's “A Boy and His Dog” (Ellison, 1969), and examine the real-world situations and concerns that these stories comment upon.
\end{abstract}

KEYWORDS: $\bullet$ doctor $\bullet$ patient $\bullet$ relationship $\bullet$ common law $\bullet$ North American Literature $\bullet$ British Literature

Correspondence AdDress: Victor Kennedy, Ph.D., Professor, University of Maribor, Faculty of Arts, Department of English and American Studies, Koroška Cesta 160, 2000 Maribor, Slovenia, email: victor.kennedy@um.si.

DOI 10.18690/24637955.9.1.1-10(2016)

ISSN 2463-7955 Print (C) 2016 LeXonomica Press

Available online at http://journals.lexonomica.press. 
V. Kennedy: The Relationship Between Doctors, Patients and the Law in North American and British Literature

According to André Picard, writing in Canada's newspaper of record, The Globe and Mail, "Most of the issues surrounding fertility are health issues, not legal issues. This is an area to be dealt with by provincial health regulators, not federal criminal law" (Picard, 2012). In Canada, Britain and the United States, this is the current legal situation, and it represents the beliefs of the majority of these countries. A minority disagree, and as we can see in the run-up to the 2016 American presidential election, this minority is becoming increasing vocal. Populist candidates for the Republican nomination, and a number of Republication governors, are trying to appeal to a right wing constituency of religious extremists by promising crackdowns on women's access to health care, outlawing abortion for any reason, defunding Planned Parenthood, and even going so far as to condone, or even encourage, violence against abortion clinics. ${ }^{2}$

In Canada, Britain, and the United States, there is one fertility issue that has become a legal issue, that of surrogate motherhood. Margaret Atwood's novel, The Handmaid's Tale (Atwood, 1985), describes a near-future post-apocalyptic dystopia in which a group of religious extremists have violently deposed the United States government and replaced it with a theocracy. ${ }^{3}$ Nuclear radiation and environmental collapse have rendered most of the population sterile, so the ruling elite resort to surrogates in order to reproduce. The novel, partly inspired by the Iranian revolution, inspired worldwide debate on the morality and legality of surrogate motherhood (Busby and Vun, 2010). ${ }^{4}$

\section{Surrogacy Legislation in Common Law Jurisdictions}

Karen Busby and Delany Vun review the history of British, Canadian and American surrogacy laws, and note that the laws in both jurisdictions differ regarding "traditional surrogacy," where the surrogate mother is also the genetic mother, and "gestational surrogacy," where the adoptive mother is the genetic mother. In Canada, surrogacy is prohibited under the federal Assisted Human Reproduction Act (AHRA), and participation in surrogacy is therefore a criminal act. ${ }^{5}$ However, the act is unenforced, and surrogacy has become commonplace. Busby and Vun conclude that most of the concerns that prompted the passing of the AHRA were unfounded:

The stories told by American and British women who have agreed to be surrogate mothers are quite different from the cautionary tale told by Atwood's handmaid and they indicate that the experience of Marybeth Whitehead, the surrogate mother in the Baby $M$ case, is the exception not the norm. The empirical research demonstrates that concerns that commercial surrogacy will lead to commodification and exploitation, and that women cannot give meaningful consent to such arrangements, have not been realized in those countries.(Busby and Vun, 2010). 
Atwood's novel addresses these fears of commodification and exploitation, as did many legal commentators and feminist writers in Canada at the time:

In economic terms, the handmaid learns to regard her function $\mathrm{s}$ a business transaction, the delivery of a service from which she is alienated, much le the sex work of a prostitute. The exchange value of her service is such that she comes to enjoy her role as a prized commodity, maximizing her value in the swish of a hip which displays her power over men, even if only as a "dog bone" thrown to those (the guardians, who have themselves been cut off from the sexual use of their own bodies) (Myrsiades,1999: 230).

The Political and Social Background of Fertility Legislation: Eugenics

Although The Handmaid's Tale refers only briefly to Nazi extermination camps (154-155), the policies of the Gilead regime resemble in many ways the eugenics program now mostly associated with the Third Reich, but which, in fact, they borrowed from America:

The most commonly suggested method of eugenicide in the United States was a lethal chamber or public, locally operated gas chambers. In 1918, Popenoe, the Army venereal disease specialist during World War I, cowrote the widely used textbook, Applied Eugenics, which argued, 'From an historical point of view, the first method which presents itself is execution ... Its value in keeping up the standard of the race should not be underestimated ... Eugenic breeders believed American society was not ready to implement an organized lethal solution. But many mental institutions and doctors practiced improvised medical lethality and passive euthanasia on their own.' (Black, 2003)

In our society, we believe that the doctor-patient relationship exists for the benefit of the patient, but in authoritarian regimes and dystopias, the doctor's allegiance is to the state, not the patient. Konrad Lorenz, winner of the 1973 Nobel Prize for Physiology or Medicine, articulated the rationale of doctors who supported the American and German eugenics programs:

There is a close analogy between a human body invaded by a cancer and a nation afflicted with subpopulations whose inborn defects cause them to become social liabilities. Just as in cancer the best treatment is to eradicate the parasitic growth as quickly as possible, the eugenic defense against the dysgenic social effects of afflicted subpopulations is of necessity limited to equally drastic measures.... When these inferior elements are not effectively eliminated from a (healthy) population, then - just as when the cells of a malignant rumor are allowed to proliferate throughout a human body - they destroy the host body as well as themselves. (Mehler, 1987) 
V. Kennedy: The Relationship Between Doctors, Patients and the Law in North American and British Literature

Stefan Kühl shows in The Nazi Connection: eugenics, American racism, and German national socialism that the eugenics movement still exerts a powerful influence in American society and policy (Kühl, 1994).

\section{$4 \quad$ Eugenics in Post-Apocalyptic Dystopias}

Gilead's authoritarian repressions is an extreme version of the conflict between public and private interests, and government interference in personal lives. Ironically, the Gilead regime twists and exaggerates principles shared by feminists; the urge to protect crosses the line into the urge to repress, as we can see in this scene from Offred' childhood, before America was replaced by Gilead, when her mother takes her to a book-burning:

You want to throw one on, honey? She said. How old was I?

Good riddance to bad rubbish, she said, chuckling. It okay? She said to my mother.

If she wants to, my mother said; she had a way of talking about me to others as if I couldn't hear

The woman handed me one of the magazines. It had a pretty woman on it, with no clothes on, hanging rom the ceiling by a chain wound around her hands. I looked at it with interest. It didn't frighten me. I thought she was swinging, like Tarzan from a vine, on the TV.

Don't let her see it, said my mother. Here, she said to me, toss it in quick.

I threw the magazine into the flames. It riffled open in the wind of its burning; big flakes of paper came loose, sailed into the air, still on fire, parts of women's bodies, turning to black ash, in the air, before my eyes. (Atwood, 1985: 48-49).

The main irony in this scene is that the child and her mother are at a feminist rally protesting pornography, which they consider demeaning to women, but it is the same urge to censor that brings about the repressive theocracy of Gilead, which turns women into the possessions of powerful men. Atwood's irony is always complex: the deeper irony is that the child is being taught to censor and condemn something she knows nothing about, and forbidden to think about it for herself. Thus, this fictitious representation of the second-wave feminist movement was susceptible to the same thought patterns as the patriarchy it sought to oppose. Atwood's satire is clearly directed toward extremism at both ends of the genderpolitics spectrum. The symbolism in the last sentence of the passage is clear; it foreshadows the effect on women and their rights of the moralist extremism of Gilead.

In the previous chapter, Offred and Ofgen attended a "Salvaging," where enemies of the regime are hanged and their bodies displayed hanging from hooks on a wall. The enemies in this scene are doctors who are suspected of having performed abortions. Offred remarks, "It's no excuse that what they did was legal at the time: their crimes are retroactive" (Atwood, 1985: 43). In this, and in several other 
passages in the novel, it becomes clear that in Gilead doctors have been marginalized, no longer the respected authority figures they were in America before the revolution. Unlike the Third Reich, in which many doctors were willing participants in repression and mass murder, in Gilead they have become as marginalized as women. ${ }^{6}$

When Offred's doctor offers to help her become pregnant, explaining that the Commander is probably sterile, she refuses, but muses that, "There is no such thing as a sterile man any more, not officially. There are only women who are fruitful and those who are barren, that's the law" (Atwood, 1985: 70-71).

The law of Gilead is patriarchal. Faith has replaced science, as authority has replaced democracy. In another ironic twist, Atwood shows that the revolution was enabled by many women, represented in the novel with the Wives and the Aunts, who advocated a return to traditional roles for women as mothers and homemakers.

Later in the novel, Serena Joy, the Commander's wife, offers to help Offred conceive, acknowledging that the Commander is probably sterile. Offred agrees, but with a condition: "Not with a doctor" (215). Serena Joy agrees: "Sometimes they blackmail. But it doesn't have to be a doctor. It could be someone we trust" (215). By this point in the story we can see that the whole society is corrupt from the top down; The Commander's Wife arranges for the chauffeur to impregnate the Handmaid, while the Commander is in the process of turning her into his mistress (in chapter 37 he takes her to a brothel reserved for the Commanders). Justifying the corruption are propaganda and lies, as familiar words and phrases are adapted for the regime's purposes:

Not every commander has a Handmaid: some of their Wives have children.

From each, says the slogan, according to her ability; to each according to

his needs. We recited that, three times, after dessert. ${ }^{7}$ It was from the Bible, or so they said (Atwood, 1985: 127).

In The Handmaid's Tale, the relationship between doctor and patient has been marginalized, as the doctor's role has been usurped by the state. When Offred attends the birth of Ofwarren's child, the birth is attended only by female members of the Commander's family (including servants), with guards posted outside, but the attending doctors are forced to wait outside in a van; "Most of the time they aren't needed at all; they're only allowed in if it can't be helped" (Atwood 1985: 124). Similarly, although the handmaids are legally required to have a monthly physical checkup, doctors are not allowed to determine the sex of the baby, and in case of defects, abortions are not permitted; the pregnancy must come to term, and the "Unbaby" be disposed of (123). 
Ofwarren's baby turns out to have been defective. The Handmaid finds out from Ofglen at a Prayvaganza: "It was no good, you know.... It was a shredder after all" (226). It turns out that Janine's Commander was not the father of her baby: 'She thinks it was her fault,' Ofglen whispers. 'Two in a row. For being sinful. She used a doctor, they say, it wasn't her Commander's at all' (227). It is not clear whether the baby was destroyed because it had physical defects or because its lineage was discovered. The utility of the underhanded reproductive activity is clear: when a baby is found to be defective, the blame can be shifted away from those in power.

One of the common concerns about surrogate motherhood during the 1980s was the fear that after bringing a baby to term, the surrogate mother would become too attached to it to give it up. This is mentioned in The Handmaid's Tale (just before it is revealed that the baby was "a shredder"):

Janine must have been transferred then, to a new household, a new posting. It's early for that, has something gone wrong with her breast milk? That would be the only reason they'd move her, unless there's been a fight over the baby; which happens more than you'd think. Once she had it, she may have resisted giving it up (226).

Literature often functions as the purveyor of a society's nightmares, but Busby and Vun, however, found that baby-ownership litigation seldom happens in North American or British surrogacy arrangements (37).

Atwood's novel is probably the best-known popular portrayal of a dystopian future in which much of the human race has been rendered sterile, but there are other science fiction novels and stories dealing in various ways with the same scenario. P.D. James's The Children of Men (James, 1992), set in Britain, also depicts a repressive regime with racist eugenics laws:

'You should give up the compulsory testing of sperm. It's degrading and it's been done now for over twenty years without success. Anyway, you only test healthy, selected males. What about the others?'

'If they can breed, good luck to them, but while there are limited facilities for the testing, let's keep it for the physically and morally fit.'

'So you're planning for virtue as well as health?'

'You could say, yes. No one with a criminal record or a family record of offending ought to be allowed to breed, if we have a choice.'

'So the criminal law is to be the measure of virtue?'

'How else can it be measured? The State can't look into men's hearts. All right, it's rough and ready and we'll disregard small delinquencies. But why breed from the stupid, the feckless, the violent?' (James, 1992).

James's England in 2021 is part of a world in which all human males spontaneously became sterile in 1994. Unlike many other post-apocalyptic dystopias, there has been no nuclear war or environmental collapse. The collapse 
here is biological and psychological. With no foreseeable future for the species, most humans have sunk into apathy, and are concerned only with comfort and security. As people age, they become more conservative, and support an unelected government that promises safety above all.

In Harlan Ellison's short story "A Boy and His Dog," set in 2014 in what was once Kansas, a nuclear war has eliminated all organized government. Roving bands of feral teenage boys roam the surface while vestiges of the old order survive in underground shelters. "Downunder" is a reconstruction of the smalltown America of the 1950s, but the aging male population, like that of Gilead and James's world, has become sterile. "A Boy and His Dog" ironically shows a teenage boy who is, like Offred, pressed into sex slavery. Ellison, like Atwood, drew inspiration from history for his dystopian vision of the future:

I used history as my model for the condition of the country in "A Boy and His Dog," where, after a decimating war, like the Wars Of The Roses, for instance, the things that become most valuable are weapons, food, and women. Women were traded and treated like chattels. I tried to make it clear in the stories and the novel that I found this distasteful, but it's the reality of what humanity's like when it's gone through this kind of apocalyptic inconvenience, if you will (Ellison, 2013).

In "A Boy and His Dog," men are chattels as well as women:

'It's nice down here. Quiet, orderly people who respect each other, no crime, respect for the elders, and just all around a good place to live. We're growin' and we're prosperin'.'

'But, well, we find now that some of our folks can't have no more babies, and the women that do, they have mostly girls. We need some men. Certain special kind of men.'

I started laughing. This was too good to be true. They wanted me for stud service. I couldn’t stop laughing. (Ellison, 1969: 237)

Although there is no central government, the survivors "downunder" have tried to hang on to their old customs and values, but have succeeded only in creating a distorted simulacrum of small-town America. In the film version, the corruption is symbolized by the grotesque makeup the "downunderers" wear. At the end of the story, when the reproductive gambit fails, Ellison's protagonist, Vic, resorts to the ultimate degrading end of humanity, cannibalism, prefiguring Cormac McCarthy's The Road (McCarthy, 2006). ${ }^{9}$

\section{5}

\section{Conclusion}

In Canada, the Canadian Criminal Law Amendment Act, S.C. 1968-69, c.38 decriminalised homosexuality and allowed abortion under certain conditions, and bill S-15, passed at the same time, decriminalised the sale of contraceptives. 
Liberal Prime Minister Pierre Trudeau told reporters that "there's no place for the state in the bedrooms of the nation," and that "what's done in private between adults doesn't concern the Criminal Code" (Trudeau, 1969).

With new technological developments in fertility treatments in the 1980s, the Canadian government did intervene in the bedrooms of the nation, but when the problems foreseen by the AHCA failed to materialize, the Act was abandoned.

Authoritarian dystopias show that Prime Minister Trudeau's liberal concepts are not universal and, reflecting reality in other places and times, such as Germany in the 1930s and 40s, Romania in the 1960s, and Iran in the 1980s, warn that state intervention in human reproduction can happen anywhere, at any time. Margaret Atwood got the idea for The Handmaid's Tale from watching television news coverage of the Iranian Revolution and of contemporary North American religious extremist groups, and imagined a future America following a similar path (Rothstein, 1986). Today, we can see American presidential candidates promising similar measures.

Post-apocalyptic dystopias examine current issues and concerns and extrapolate to their logical extremes. Ellison's, James's and Atwood's visions of the future examine current social and moral attitudes toward reproduction that lead to the authoritarian impulse to control it. ${ }^{10}$ In their imagined worlds, which are threatened with extinction because of man-made sterility, reproduction as a matter of survival has become a public, rather than private, affair, but all three authors show how issues of ostensibly public interest can become twisted by selfish concerns.

\footnotetext{
Notes

${ }^{1}$ In Ontario, Canada, it is the College of Physicians and Surgeons of Ontario (CPSO). In Britain, the General Medical Council.

${ }^{2}$ On 27 November, 2015, Robert Dear shot and killed three people at a Planned Parenthood clinic in Colorado Springs, Colorado. He attempted to justify the shooting by saying "no more baby parts," a reference to a series of videos that had been circulated claiming that Planned Parenthood was selling fetal tissues harvested from abortions (Siddiqui, 2015). Eight state investigations failed to find any evidence to support the claims of the videos, and on January 14, 2016, Planned Parenthood filed suit in Federal Court in San Francisco alleging "that the Center for Medical Progress and its contributors and advisers, who are individually named, broke federal and state laws, including the Racketeer Influenced and Corrupt Organizations Act, known as RICO, as well as invasion of privacy and recording laws. It asks for extensive monetary damages, saying Planned Parenthood providers have faced death threats, been forced to move or go into hiding and been picketed at their homes" (Carmon, 2016). There have been multiple murders, bombings, and arson at abortion clinics in the United States, Canada, and Britain. Anti-abortion extremists are now considered to be a domestic terrorist threat (Jefferis, 2011)(40).

${ }^{3}$ The novel was adapted into a film (Schlöndorff, 1990). A similar scenario appears in P.D. James's novel Children of Men (James, 1992) and its film adaptation (Cuarón, 2006).

${ }^{4}$ There are other historical precedents to Atwood's fictional events. The novel's postscript also mentions that "Romania, for instance, had anticipated Gilead in the eighties by
} 
banning all forms of birth control, imposing compulsory pregnancy tests on the female population, and linking promotion and wage increases to fertility" (317). Atwood's pompous academic narrator is referring, anachronistically, to the Ceausescu regime's 1966 Decree 770 (Berelson, 1979).

${ }^{5}$ In ... 2012, the Government of Canada announced that it would wind down AHRC, in response to the 2010 ruling of the Supreme Court of Canada that significantly reduced the federal role in assisted human reproduction (Canada).

${ }^{6}$ The Rockefeller Foundation helped found the German eugenics program and even funded the program that Josef Mengele worked in before he went to Auschwitz (Black 2003b).

7 "after dessert" is a typical example of Atwood's satire. An inversion of "the grace" spoken before a meal, the thrice-repeated, perverted, incantation has become the Gileadan equivalent of a Black Mass.

${ }^{8}$ In an ironic inversion of H.G. Well's The Time Machine (Wells, 1895), the inhabitants of "Downunder" raid the surface not to feed, but to breed, and in the end it is the relatively innocent surface dweller Vic who cannibalizes Quilla June, Ellison's version of The Morlocks.

${ }^{9}$ The Road is an extreme post-apocalyptic story; unlike a dystopia, in which order has become corrupted, all order has disappeared, leaving only anarchy.

${ }^{10}$ In a similar situation, the apocalyptic ending of mankind, Stanley Kubrick's Doctor Strangelove proposes how people would be selected for a breeding colony: "a computer could be set and programmed to accept factors from youth, health, sexual fertility, intelligence, and a cross section of necessary skills. Of course it would be absolutely vital that our top government and military men be included to foster and impart the required principles of leadership and tradition" (Kubrick 1964).

\section{References}

Atwood, M. (1985) The Handmaid's Tale (Toronto: McClelland and Stewart).

Berelson, B. (1979) Romania's 1966 Anti-Abortion Decree: the demographic experience of the first decade, Population Studies, 33(2), pp. 209-222.

Black, E. (2003) Eugenics and the Nazis-the California connection (excerpt), San Francisco Chronicle, Sunday, November 9, 2003, D-1.

Black, E. (2016) The Horrifying American Roots of Nazi Eugenics, History News Network , available at http://historynewsnetwork.org/article/1796_February 7, 2016).

Busby, K. \& Vun, D. (2010) Revisiting The Handmaid's Tale: Feminist Theory Meets Empirical Research on Surrogate Motherhood, Canadian Journal of Family Law, 26(1), pp. 13-93.

Canada Health (2004) Assisted Human Reproduction Act, available at http://www.hcsc.gc.ca/dhp-mps/brgtherap/legislation/reprod/index-eng.php (January 18, 2016)

Carmon, I. (2016) Planned Parenthood sues anti-abortion group behind secret videos, $M S N B C$, available at http://www.msnbc.com/msnbc/planned-parenthood-sues-antiabortion-group-behind-secret-videos (February 18, 2016)

Cuarón, A. (2006) Children of Men (Universal City, LA: Universal Pictures).

Ellison, H. (1969) The Beast that Shouted Love at the Heart of the World (New York: Avon).

Ellison, H. (2013) Harlan Ellison on taking flak for, but admiring, A Boy and His Dog, available at https://thedissolve.com/features/interview/73-harlan-ellison-on-taking-flakfor-but-admiring-a-b/ (February 4, 2016). 
V. Kennedy: The Relationship Between Doctors, Patients and the Law in North American and British Literature

Dorr Goold, S. \& Lipkin, M. Jr. (1999) The Doctor-Patient Relationship: challenges, opportunities, strategies." Journal of General Internal Medicine, 14(Suppl 1), pp. S26S33.

James, P. D. (1992) The Children of Men (London: Faber).

Jefferis, J. L. (2011) Armed for Life: the Army of God and anti-abortion terror in the United States, PSI guides to terrorists, insurgents, and armed groups (Santa Barbara, California: Praeger).

Kubrick, S. (1964) Dr. Strangelove; or, How I Learned to Stop Worrying and Love the Bomb, (Hollywood: Columbia Pictures).

Kühl, S. (1994) The Nazi Connection: eugenics, American racism, and German national socialism. (New York: Oxford University Press).

McCarthy, C. (2006) The Road, 1st ed. (New York: Alfred A. Knopf).

Mehler, B. (1987) Eliminating the Inferior: American and Nazi Sterilization Programs, Science for the People, 19(6), pp. 14-18.

Myrsiades, L. (1999) CHAPTER ELEVEN: Law, Medicine, and the Sex Slave in Margaret Atwood's "The Handmaid's Tale", Counterpoints, 121, pp. 219-245.

Picard, A. (2012) Canada's Fertility Law Needs a Reset, The Globe and Mail, April 2.2012.

Rothstein, M. (1986) No Balm in Gilead for Margaret Atwood, The New York Times, February 17, 1986.

Schlöndorff, V. (1990) The Handmaid's Tale. (U.S.: Metro Goldwyn Mayer).

Siddiqui, S. (2015) Republicans reject link between anti-abortion rhetoric and Colorado shooting, The Guardian, November 29, 2015.

Trudeau, P. (1969) Trudeau: "There's no place for the state in the bedrooms of the nation". (Ottawa, Canada: Canadian Broadcasting Corporation).

Wells, H. G. (1895) The Time Machine; an invention (London: W. Heinemann). 